\title{
Gambaran Klinis dan Kelainan Imunologis pada Anak dengan Lupus Eritematosus Sistemik di Rumah Sakit Umum Pusat Adam Malik Medan
}

Evalina R

Departemen Ilmu Kesehatan Anak, Fakultas Kedokteran Universitas Sumatera Utara, Rumah Sakit Umum Pusat Adam Malik, Medan

Latar belakang. Lupus eritematosus sistemik (LES) adalah penyakit autoimun sistemik yang disebabkan oleh keterkaitan faktor lingkungan, hormonal dan genetik. Manifestasi klinis dan hasil laboratorium diperlukan untuk menegakkan diagnosis LES.

Tujuan. Untuk melihat pola gambaran klinis dan abnormalitas laboratorium pada anak LES yang datang ke Poli Alergi Imunologi Anak Rumah Sakit Umum Pusat Adam Malik, Medan.

Metode. Penelitian merupakan studi deskriptif terhadap 12 anak dengan diagnosis LES berdasarkan kriteria American College of Rheumatology (ACR) revisi yang datang ke Poliklinik Alergi Imunologi Anak RSUP Adam Malik Medan sejak tahun 2006-2010. Catatan medis pasien LES dikumpulkan untuk melihat gambaran klinis dan kelainan imunologis.

Hasil. Dua belas pasien memenuhi kriteria ACR yang direvisi, terdiri dari 11 anak perempuan dan satu anak laki-laki, dengan rerata usia 10,25 (antara 3-15 tahun). Semua pasien dengan manifestasi klinis demam, ruam kulit berbentuk kupu-kupu, nyeri sendi dan penurunan berat badan. Pemeriksaan laboratorium pada semua pasien menunjukkan anemia, test ANA positif, dan kenaikan titer anti ds-DNA

Kesimpulan. Demam, ruam kupu-kupu, nyeri sendi dan penurunan berat badan merupakan manifestasi klinis yang paling sering dan ditemukan pada semua pasien.Anemia, test ANA positif, dan kenaikan titer anti-dsDNA juga ditemukan pada semua pasien. Sari Pediatri 2012;13(6):406-11.

Kata kunci: LES, anak, gambaran klinis, pemeriksaan laboratorium

\footnotetext{
Alamat korespondensi:

Dr. Evalina R, Sp.A. Departemen Ilmu Kesehatan Anak Fakultas Kedokteran Universitas Sumatera Utara/ RSUP H.Adam Malik Jl. Bunga Lau no.17 Medan. Telp. (061) 8361721 - 8365663, Fax. (061) 8361721 E-mail: ritaerusli@yahoo.co.id; kotak Pos697 Medan-20136.
}

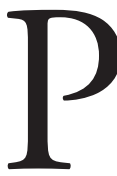

enyakit Lupus eritematosus sistemik (LES) merupakan penyakit sistemik evolutif yang mengenai satu atau beberapa organ tubuh, seperti ginjal, kulit, sel darah dan sistem saraf, ditandai oleh inflamasi luas pada pembuluh darah dan jaringan ikat, bersifat episodik diselingi oleh periode remisi, dan karakteristik adanya autoantibodi, khusus- 
nya antibodi antinuklear dan aktivasi komplemen. ${ }^{1-2}$ Insidens LES pada anak secara umum mengalami peningkatan, sekitar 15-17\%. Penyakit ini jarang terjadi pada usia di bawah 5 tahun, perempuan lebih sering terkena dibandingkan laki-laki dan rasio tersebut juga meningkat seiring dengan pertambahan usia. Onset LES paling sering didapatkan pada anak perempuan usia antara 9 sampai 15 tahun. Rasio perempuan dan laki-laki adalah 2:1 sebelum pubertas dan setelah pubertas menjadi 9:1. Insidens LES tidak diketahui secara pasti tapi bervariasi tergantung etnis dan lokasi. Prevalens LES antara 2,9-400/100.000. ${ }^{3}$

Tabel 1. Kriteria diagnosis lupus menurut ACR (American College of Rheumathology)

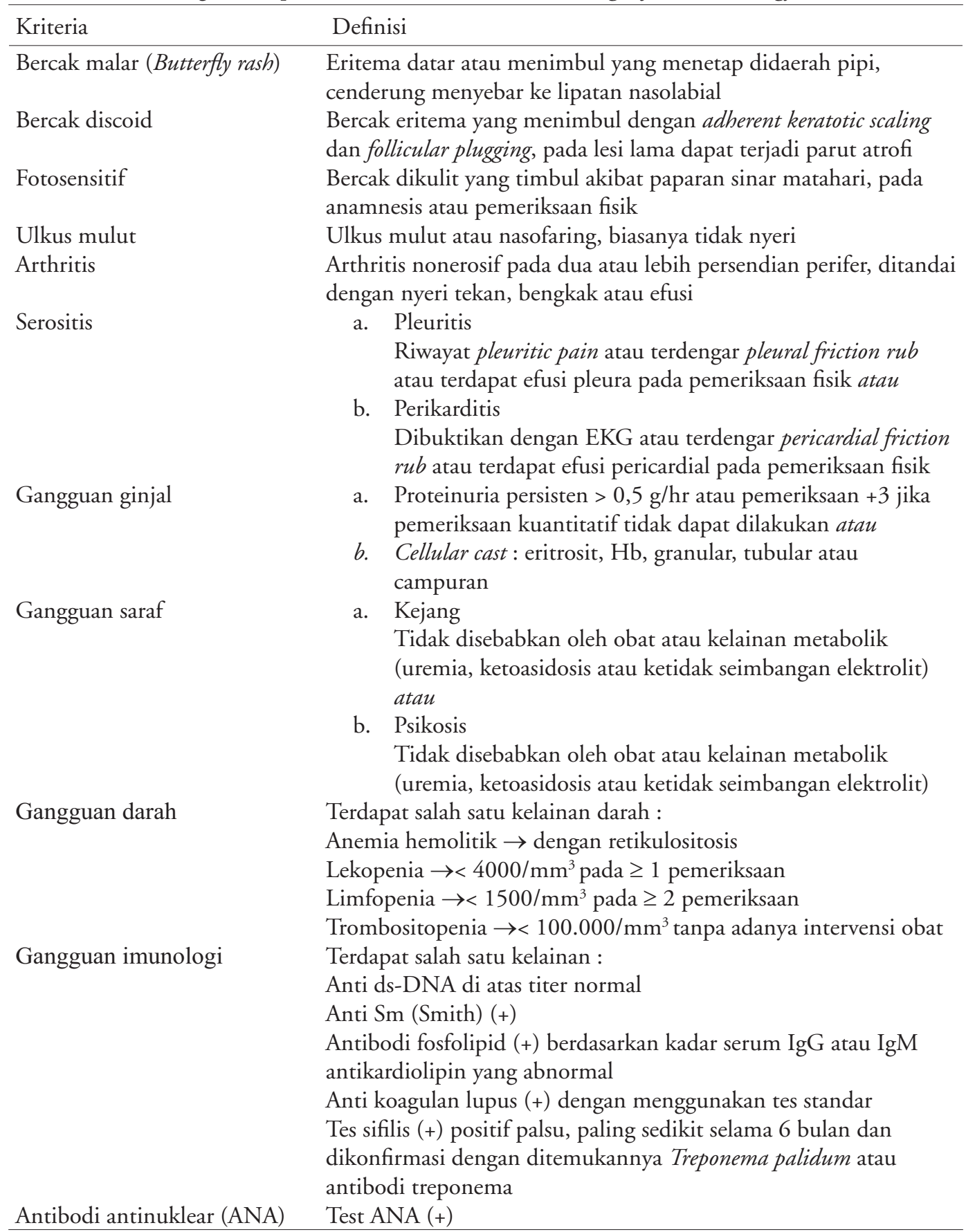


Klasifikasi LES mengacu pada klasifikasi yang dibuat oleh American College of Rheumatology (ACR) pada tahun 1982 dan dimodifikasi pada tahun 1997. Kriteria diagnosis pada anak berdasarkan kriteria tersebut mempunyai sensitivitas $96 \%$ dan spesifisitas 100\%. Diagnosis LES ditegakkan bila terdapat paling sedikit 4 dari 11 kriteria ACR tersebut. ${ }^{1,3-7}$

Peningkatan nilai ANA (anti nuclear antibody) pada pemeriksaan laboratorium mempunyai sensitivitas $95 \%$ dan spesifisitas 50\% untuk menegakkan diagnosis LES dan merupakan tes skrining yang terbaik. Sementara pemeriksaan anti-double stranded DNA mempunyai nilai diagnostik lebih dari $75 \%$ dan menunjukkan derajat aktivitas penyakit.,

Tata laksana LES tergantung sistem organ yang terlibat dan beratnya penyakit serta toksisitas diusahakan seminimal mungkin. Golongan kortikosteroid dapat mengontrol gejala dan produksi autoantibodi pada LES.

\section{Metode}

Penelitian merupakan studi deskriptif. Data diperoleh dari rekam medis pasien yang datang ke Poliklinik Alergi Imunologi Departemen Ilmu Kesehatan Anak RSUP Adam Malik dengan diagnosis LES dari Januari 2006 sampai Desember 2010. Diagnosis LES pada anak berdasarkan anamnesis, gejala klinis dan dengan pemeriksaan laboratorium penunjang. Diagnosis LES dapat ditegakkan bila terdapat 4 dari 11 kriteria ACR (Tabel 1). ${ }^{1}$

Manifestasi klinis LES bervariasi antara penyakit kronik dengan riwayat keluhan dan gejala intermiten hingga fase akut yang fatal. Gejala konstitusional dapat berupa demam yang menetap atau intermiten, kelelahan, penurunan berat badan dan anoreksia. Satu sistem organ dapat terkena, meskipun penyakit multisistem lebih khas. ${ }^{1,3-5}$

Pemeriksaan laboratorium meliputi pemeriksaan indikator inflamasi, uji autoantibodi (khususnya ditujukan pada antigen nuklear), pemeriksaan untuk evaluasi keterlibatan organ dan pemeriksaan untuk memantau efek terapi termasuk toksisitas obat. ${ }^{1,9,10}$ Semua pasien dengan diagnosis LES pada penelitian ini diamati karakteristik umum, gejala klinis dan hasil pemeriksaan laboratorium. Data diolah dan dianalisis dengan menggunakan SPSS versi 13 .

\section{Hasil}

Penelitian ini diamati selama periode 5 tahun mulai dari Januari 2006 sampai Desember 2010 dan terdapat 12 anak dengan diagnosis LES, terdiri dari 1 (satu) anak laki-laki (8,3\%) dan 11 (sebelas) anak perempuan $(91,7 \%)$ dengan perbandingn 1:11. Rerata usia saat datang ke fasilitas kesehatan adalah 10,25 tahun dengan rentang usia antara 3 sampai 15 tahun. Keluhan utama saat pertama kali datang 100\% adalah demam, ruam kupu-kupu, nyeri sendi dan penurunan berat badan yang didapatkan pada semua pasien. Pada pemeriksaan laboratorium pasien, semua pasien menunjukkan anemia, test ANA positif, dan kenaikan titer anti ds-DNA. Satu pasien (1/12) datang dalam kondisi malnutrisi berat, 3 orang (3/12) dengan malnutrisi sedang dan sebagian besar (8/12) tanpa malnutrisi. Karakteristik umum subyek penelitian ini tertera pada Tabel 2.

Manifestasi klinis yang lain saat pertama datang yaitu rambut rontok pada 10 pasien, bercak diskoid pada 1 pasien, fotosensitif 10 pasien, ulkus dimulut 4 pasien, serositis pada 8 pasien, arthritis pada 5 pasien, gangguan ginjal pada 6 pasien, kejang pada 1 dan bronkopnemonia pada 1 pasien. Pada pemeriksaan laboratorioum yang lain adalah peningkatan laju endap darah (LED) pada 8, lekopenia terdapat pada 6 pasien, CRP positif pada 7 pasien, dan penurunan C3 pada 9 pasien. Data pasien berdasarkan kriteria ACR tertera pada Gambar 1.

Tabel 2. Karakteristik umum subyek penelitian

\begin{tabular}{lc}
\hline Karakteristik subyek & Total (\%) \\
\hline Jenis kelamin & \\
$\quad$ Laki-laki & 1 \\
$\quad$ Perempuan & 11 \\
Keluhan utama & \\
$\quad$ Demam & 12 \\
Ruam kupu-kupu & 12 \\
Nyeri sendi & 12 \\
Penurunan berat badan & 12 \\
Usia saat terdiagnosis (tahun) & \\
0-5 & 1 \\
6-10 & 5 \\
>10 & 6 \\
Status nutrisi saat terdiagnosis & \\
Malnutrisi berat & 1 \\
Malnutrisi sedang & 3 \\
Tanpa malnutrisi & 8
\end{tabular}




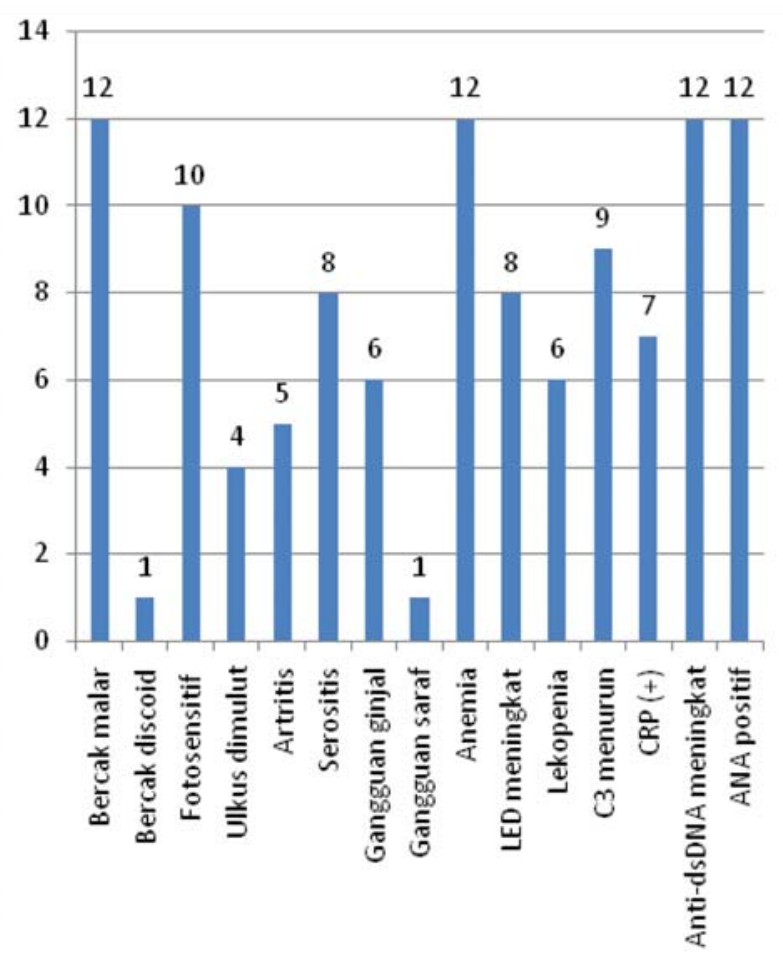

Gambar 1. Gambaran gejala klinis dan laboratoris berdasarkan kriteria ACR

\section{Pembahasan}

Etiologi penyakit LES merupakan interaksi antara faktor genetik, faktor yang didapat dan faktor lingkungan yang berakibat terjadinya gangguan imunitas yang ditandai oleh persistensi limfosit $\mathrm{B}$ dan $\mathrm{T}$ yang bersifat autoreaktif. Autoantibodi akan berikatan dengan autoantigen membentuk kompleks imun yang mengendap berupa depot dalam jaringan. Akibatnya akan terjadi aktivasi komplemen sehingga terjadi reaksi inflamasi yang menimbulkan lesi di tempat tersebut. ${ }^{1,3-5}$

Ruam malar merupakan manifestasi kulit yang paling sering dan paling mudah dilihat, merupakan gejala umum selama proses aktif penyakit. Manifestasi malar rash pada penelitian oleh Ghaffarpas adalah 60,48\%. ${ }^{11}$ Ruam klasik (butterfly rash) terjadi pada sepertiga sampai setengah pada kasus anak saat onset penyakit namun bukan gejala yang patognomonik. Ruam ini biasanya simetrik di kedua malar, jembatan hidung, dahi namun tidak sampai lipatan nasolabial. ${ }^{1,5}$ Pada penelitian ini kami mendapatkan ruam malar pada semua subyek dan merupakan keluhan yang membuat pasien datang berobat.
Lesi diskoid jarang terjadi pada anak, biasanya terjadi di kepala atau ekstremitas dengan distribusi yang asimetris. Lesi ini predominan pada perjalanan penyakit lupus kronik. ${ }^{1}$ Dilaporkan anak dengan diskoid lupus sebanyak 2\%-3\%. ${ }^{12}$ Kami mendapatkan satu anak dengan lesi diskoid.

Artralgia dan artritis terjadi pada sebagian besar anak dengan LES. ${ }^{1,3,5,7,9}$ Artralgia didapatkan pada semua anak, sedangkan artritis terjadi pada lima anak. Poliserositis dapat meliputi pleuritis dengan efusi, peritonitis dan perikarditis. ${ }^{1,4,5}$ Penyakit LES dapat mengenai perikardium, miokardium, endokardium serta arteri dan vena koroner. Valvulitis, gangguan hantaran dan hipertensi sering terjadi pada pasien LES. Manifestasi kardiologi yang paling sering dijumpai adalah efusi perikardium. ${ }^{5-7}$ Didapatkan delapan pasien pada penelitian ini dengan efusi perikardium.

Kelainan ginjal ditemukan pada 60\%-80\% anak dengan LES. Urinalisis yang abnormal adalah indikasi untuk adanya gangguan pada ginjal. ${ }^{3,4,7,8}$ Proteinuria adalah temuan abnormal yang paling sering dan merupakan kriteria yang penting untuk menegakkan diagnosis lupus nefritis. ${ }^{1,-9}$ Lupus nefritis merupakan penentu utama dalam prognosis jangka panjang. Nefritis lebih sering terjadi pada anak dibandingkan dewasa. Lupus nefritis biasanya asimtomatik, meskipun pada beberapa anak terdapat hematuria makroskopik atau edema yang berkaitan dengan sindroma nefrotik. ${ }^{1,8,13}$ Pada penelitian ini terdapat enam anak dengan gangguan ginjal dan ditegakkan diagnosis sebagai lupus nefritis berdasarkan hasil pemeriksaan urinalisis yaitu terdapatnya protein, eritrosit, dan lekosit. Hampir dua pertiga anak dan remaja yang terdiagnosis LES berkembang menjadi penyakit ginjal. ${ }^{14}$

Rambut rontok sering juga dikeluhkan pada saat pertama kali datang. Rambut rontok bisa disebabkan oleh penyakitnya sendiri yaitu sistem imun yang merusak folikel rambut atau oleh karena pengobatan LES. Mukosa oral merupakan tempat tersering terjadinya ulserasi pada anak dengan LES. Lesi klasik biasanya tidak nyeri, dalam, berupa ulkus kasar, dan disertai eritema pada palatum durum. ${ }^{1,15}$

Artalgia dan artritis terjadi pada sebagian besar anak dengan LES, Semua sendi besar dan kecil bisa terlibat, sendi kecil yang terlibat biasanya sendi kecil ditangan, pergelangan tangan, siku, bahu, lutut dan pergelangan kaki. Manifestasi utama pada sendi adalah berupa kekakuan, nyeri dan inflamasi. Pola artritis adalah rekuren, sering menghilang tapi kemudian 